\title{
Density of Diachasmimorpha longicaudata (Ashmead) and host Ceratitis capitata (Wied) larvae for the increase of parasitoid female production
}

\author{
Densidade de Diachasmimorpha longicaudata (Ashmead) e do hospedeiro \\ Ceratitis capitata (Wied) no incremento da produção de fêmeas do parasitoide

\begin{abstract}
Carlos Gustavo da Cruz ${ }^{*}$, Clarice Diniz Alvarenga', Patricia Cristina do Carmo Oliveira', Edileuza dos Reis Souza Conceição', Zenobia Cardoso dos Santos', Teresinha Augusta Giustolin', Maria das Dores da Cruz Souza'
\end{abstract}

\begin{abstract}
The objective of the present study was to evaluate the ratio of Ceratitis capitata larvae/female of Diachasmimorpha longicaudata that results in the increase of parasitism and the production of females in the progeny. We used 8-day-old copulated D. longicaudata females with oviposition parasite experience and third instar larvae of $C$. capitata from rearing stock maintained at the Laboratory of Biological Control of Universidade Estadual de Montes Claros (Unimontes). Five densities of C. capitata larvae $(10,20,30,40$, and 50) were offered to parasitoid females that were at five different densities (1, 2, 5, 10, and 15). The larvae were exposed to the parasitoid females by means of "parasitism units" in adapted cages for 1 hour. Sex ratio, percentage of parasitism, and pupal mortality were evaluated. Both host larval density and female parasite density influenced parasitism, female progeny production, and pupal mortality. Higher female production was observed in the progeny in ratios of 1:1 and 2:1 (larvae/females). Ratios above 1:2 reduced the sex ratio, and ratios below 1:1 caused high pupal mortality rates. The females had higher parasitism activity when they were in groups dividing the same space. Equal ratios of Ceratitis capitata larvae and parasitoid females resulted in improved efficiency in progeny females.
\end{abstract}

KEYWORDS: biological control; sex ratio; fruit flies; parasitism.
RESUMO: Objetivou se neste estudo avaliar a proporção de larvas de Ceratitis capitata e fêmeas de Diachasmimorpha longicaudata que resulta no incremento do parasitismo e da produção de fêmeas na progênie. Foram utilizadas fêmeas de Diachasmimorpha longicaudata copuladas, com experiência em parasitar e oito dias de idade, e larvas de terceiro instar de C. capitata, provenientes da criação mantida no Laboratório de Controle Biológico da Universidade Estadual de Montes Claros (UNIMONTES). Cinco densidades de larvas de C. capitata foram oferecidas $(10,20,30,40$ e 50) às fêmeas do parasitoide, em cinco densidades diferentes (1, 2, 5, 10 e 15). As larvas foram expostas às fêmeas do parasitoide por meio de "unidades de parasitismo", em gaiolas adaptadas, pelo tempo determinado de uma hora. Foram avaliadas as variáveis: razão sexual, porcentagem de parasitismo e mortalidade pupal. Tanto a densidade de larvas de $C$. capitata quanto a densidade de fêmeas do parasitoide influenciaram no parasitismo, na produçâo de fêmeas na progênie e na mortalidade pupal. Foi observada nas proporçôes 1:1 e 1:2 (larvas/fêmeas) maior produção de fêmeas na progênie. Proporçôes acima de 1:2 reduziram a razão sexual, e valores abaixo de 1:1 causaram altas porcentagens de mortalidade pupal. As fêmeas apresentaram maior atividade de parasitismo quando estavam em grupos dividindo o mesmo espaço. Proporções iguais de larvas de C. capitata e fêmeas do parasitoide resultaram em melhor eficiência na produção de fêmeas na progênie.

PALAVRAS CHAVE: controle biológico; razão sexual; moscasdas-frutas; parasitismo. 


\section{INTRODUCTION}

Diachasmimorpha longicaudata (Ashmead) (Hymenoptera: Braconidae) is one of the most important parasitoid species for the biological control of fruit flies. The prominence of this species is attributed to its rapid adaptation to the media in which it is released, its great affinity with Tephritidae, and the ease of rearing it in the laboratory (GARCIA; RICALDE, 2012).

Despite its prominence, the success of $D$. longicandata as a control agent depends on its parasitism efficiency, and the quality and quantity of parasitoid females produced and released in the area to be controlled. Thus, the main objective of the mass production of this parasitoid is higher female production, since the higher the number of females produced, the more efficient and cheap will be their production, and the more accessible will be their use in biological control programs (OLIVEIRA et al., 2014). Thus, knowledge of the factors that maximize female progeny production is essential for the success of the parasitoids rearing aimed at augmentative releases (MONTOYA et al., 2011).

Variations in the number of females and males in D. longicaudata offspring occur due to the size of the host (also referred to as the quality of the host) (OLIVEIRA et al., 2014), the occurrence of superparasitism (MONTOYA et al., 2011, 2012), the competition among females (ALVARENGA et al., 2016), and the host density and availability (DIAZ-FLEISCHER et al., 2015). D. longicaudata females tend to increase their parasitism activity when the space is divided with co-specific females, which can lead to superparasitism (ALVARENGA et al., 2016). The density of the host can also influence the sex ratio, as lower densities of larvae might stimulate parasitism (DIAZ-FLEISCHER et al., 2015).

Knowing the importance of females for mass rearing and biological control, the objective of the present study was to determine the ideal ratios of host larvae of $C$. capitata per female of the $D$. longicaudata parasitoid that would result in an increase in parasitism and in the production of female offspring.

\section{MATERIALS AND METHODS}

Eight-day-old females of the parasitoid D. longicaudata and third instar larvae of C. capitata were utilized in the present study. The insects were sourced from the Laboratory of Biological Control of Universidade Estadual de Montes Claros (Unimontes), where they were maintained under controlled conditions (temperature of $25 \pm 1^{\circ} \mathrm{C}$, relative humidity of $65 \pm 10 \%$, and photoperiod of 12 hours).

To obtain the larvae, C. capitata eggs were collected from the colony stored in the laboratory and distributed to plastic containers $(24 \times 17 \times 7.5 \mathrm{~cm})$, in which the fruit fly larvae were fed on an artificial diet based on the methodology described by CARVALHO et al. (1998). The containers containing the eggs and artificial diet were stored in the laboratory $\left(25 \pm 1{ }^{\circ} \mathrm{C}\right.$, relative humidity of $65 \pm 10 \%$, and photoperiod of 12 hours), and they remained there until the larvae reached the third instar.

The parasitoid females were taken from the stock cultures, already copulated and with oviposition experience. These females were transferred to adapted cages, which were made from clear plastic containers $(11 \mathrm{~cm}$ in diameter and $8 \mathrm{~cm}$ in height). In the lids of the containers, a circular cut $(6 \mathrm{~cm}$ in diameter) was made onto which a fine voile-type fabric was glued, which aimed to allow air to enter, yet preventing the escape of insects. In each cage, different numbers of the parasitoid females $(1,2,5,10$, and 15) were placed, which were fed an artificial diet composed of honey and water, following the methodology described by CARVALHO et al. (1998).

C. capitata larvae were offered to the parasitoid females in five different densities $(10,20,30,40$, or 50$)$. These larvae were exposed to parasitism by means of "parasitism units," which consisted of the larvae and diet surrounded by a piece of voile that were hung inside the cages to simulate infested fruits. The larvae were exposed for 1 hour in cages containing different densities of the parasitoid females. After parasitism, the contents of the "parasitism units" were transferred to a plastic container of $180 \mathrm{~mL}$ capacity, which contained a thin layer of vermiculite previously moistened, covered with a voile tissue, and waited for pupation and subsequent emergence.

After emergence, the number of parasitoid females and males, number of flies, and number of dead puparia were quantified. The sex ratio was calculated using the formula: number of females/(number of males + number of females). The parasitism rate was calculated based on the formula: number of parasitoids/(number of parasitoids emerged + number of fruit flies emerged), as recommended by CARVALHO (2003). Mortality was obtained by calculating the number of non-emerged puparia divided by the number of larvae offered.

The experimental design was completely randomized in a $5 \times 5$ factorial scheme ( 5 females/cage densities and five larval densities/"parasitism unit") and 12 replicates. The data were submitted to analysis of variance and, in case of significance, the averages were compared by the Tukey's test at $5 \%$ probability. Analyses were performed using the statistical program Sisvar (FERREIRA, 2000).

\section{RESULTS}

There was a significant interaction between the number of females in the cage and larval density in relation to sex ratio 
( $\mathrm{p}<0.05, F=4.377)$. When using a density of 10 larvae per "parasitism unit," the highest sex ratio was observed for 10 females/ cage, i.e., the ratio of 1:1 (larvae/females). The lowest sex ratio was observed when 10 host larvae were offered to 15 females, i.e., more than one female for each larva. When using 20,30 , and 50 larvae, the lowest sex ratio was observed for the density of 2 females/cage. Thus, ratios of 10:1, 15:1, and 25:1 lar$\mathrm{vae} /$ females, respectively, differed significantly from the other female densities (Table 1). However, regardless of the density of larvae offered, the highest sex ratio was verified when 10 females per cage $(68.30 \%)$ were added and, irrespective of the number of females in the cage, the sex ratio was higher when 10 larvae of $C$. capitata were offered.

There was a significant interaction between the number of females in the cage and larval density in relation to the parasitism rate $(\mathrm{p}<0.05, F=5.869)$. The percentage of parasitism was significantly reduced based on the increase in larval density, except for the treatment in which 15 females were offered; in this case, the results were similar for all densities (Table 2). In contrast, the parasitism rate increased with the increase in the density of females/cage.

The lowest parasitism rate was observed when the females were isolated, that is, just one female in one cage or dividing the same space with just one more female in the cage, which was observed at all larval densities. When the density of five females was used, the highest parasitism rates were observed for the densities of 10 and 20 larvae, i.e., ratios of 2:1 and 3:1 larvae/females. With the increase in the number of females per cage (10 and 15), there was increase in the parasitism, being on average above $90 \%$. There was no significant difference between larval densities when 15 females/cage were offered (Table 2). Regardless of the density of the larvae used, the highest percentage of parasitism was observed at densities of 10 and 15 females per cage $(90.22$ and $93.91 \%$, respectively). Conversely, when 10 larvae of C. capitata were applied, regardless of the density of females, the highest parasitism rate was observed.

There was a significant interaction between the number of females in the cage and larval density in relation to pupal mortality ( $\mathrm{p}<0.05 ; F=5.056)$. When one, two, five, and ten females/cage were added, there was no significant difference between larval densities for mortality, except for the density of 50 larvae, in which the lowest mortality was observed in comparison to the other treatments. The highest mortality percentages were observed in the treatment with 15 females in all evaluated larval densities (Table 3). The highest mortality of larvae was observed in the density of 10 host larvae for 15 females. Regardless of the density of larvae added, the highest mortality percentage was verified in the density of 15 females per cage (35.68\%), and, no matter the density of females, the highest mortality was observed when 10 larvae of $C$. capitata $(26.83 \%)$ were added.

Table 1. Sex ratio (\%) of Diachasmimorpha longicaudata from the parasitism of Ceratitis capitata larvae.

\begin{tabular}{|c|c|c|c|c|c|c|}
\hline \multirow{2}{*}{$\begin{array}{l}\text { Number } \\
\text { of females }\end{array}$} & \multicolumn{5}{|c|}{ Number of larvae } & \multirow{2}{*}{ Mean } \\
\hline & 10 & 20 & 30 & 40 & 50 & \\
\hline 1 & $66.59 \mathrm{Ba}$ & $58.17 \mathrm{Aa}$ & $76.53 \mathrm{Aa}$ & $61.23 \mathrm{Aa}$ & $65.81 \mathrm{Aa}$ & $65.67 \mathrm{AB}$ \\
\hline 2 & $54.58 \mathrm{Ba}$ & $27.50 \mathrm{Bb}$ & $21.47 \mathrm{Bb}$ & 35.86 Aab & 28.65 Bab & $33.61 \mathrm{C}$ \\
\hline 5 & $74.17 \mathrm{ABa}$ & $53.71 \mathrm{ABa}$ & $53.80 \mathrm{Aa}$ & $49.07 \mathrm{Aa}$ & $56.64 \mathrm{Aa}$ & $57.48 \mathrm{AB}$ \\
\hline 10 & $94.17 \mathrm{Aa}$ & 78.57 Aab & $60.99 \mathrm{Abc}$ & 49.73 Ad & $58.05 \mathrm{Abc}$ & $68.30 \mathrm{~A}$ \\
\hline 15 & $25.08 \mathrm{Cb}$ & $74.09 \mathrm{Aa}$ & $66.53 \mathrm{Aa}$ & 50.92 Aab & $52.82 \mathrm{ABa}$ & $53.79 \mathrm{~B}$ \\
\hline Mean & $62.92 a b$ & $58.41 \mathrm{ab}$ & $55.77 a b$ & $49.36 \mathrm{~b}$ & $52.39 \mathrm{ab}$ & \\
\hline $\mathrm{CV}$ & & & & & & \\
\hline
\end{tabular}

'Different letters mean significance between the means, in the lines (lower case) and columns (upper case) ( $p<0.05)$; CV: coefficient of variation.

Table 2. Parasitism rates (\%) of Diachasmimorpha longicaudata in Ceratitis capitata larvae.

\begin{tabular}{|c|c|c|c|c|c|c|}
\hline \multirow{2}{*}{$\begin{array}{l}\text { Number } \\
\text { of females }\end{array}$} & \multicolumn{5}{|c|}{ Number of larvae } & \multirow{2}{*}{ Mean } \\
\hline & 10 & 20 & 30 & 40 & 50 & \\
\hline 1 & $61.39 \mathrm{Ba}$ & $26.82 \mathrm{Cb}$ & $14.40 \mathrm{Cb}$ & $9.05 \mathrm{Cb}$ & $9.58 \mathrm{Db}$ & $24.25 \mathrm{D}$ \\
\hline 2 & $66.53 \mathrm{Ba}$ & $45.40 \mathrm{Bb}$ & $30.45 \mathrm{Cbc}$ & $13.87 \mathrm{Cc}$ & 16.65 Dc & $34.58 \mathrm{C}$ \\
\hline 5 & 93.87 Aa & 85.87 Aa & $78.90 \mathrm{Bab}$ & $61.28 \mathrm{Bb}$ & $37.10 \mathrm{Cc}$ & $71.40 \mathrm{~B}$ \\
\hline 10 & 100.00 Aa & $98.30 \mathrm{Aa}$ & $97.05 \mathrm{Aa}$ & $90.50 \mathrm{Aa}$ & $65.25 \mathrm{Bb}$ & $90.22 \mathrm{~A}$ \\
\hline 15 & $88.19 \mathrm{Aa}$ & $99.47 \mathrm{Aa}$ & $98.86 \mathrm{Aa}$ & $93.09 \mathrm{Aa}$ & $89.94 \mathrm{Aa}$ & $93.91 \mathrm{~A}$ \\
\hline Mean & $81.99 a$ & $71.17 b$ & $63.94 b$ & $53.56 \mathrm{c}$ & $43.70 \mathrm{~d}$ & \\
\hline $\mathrm{CV}$ & \multicolumn{6}{|c|}{25.29} \\
\hline
\end{tabular}

'Different letters mean significance between the means, in the lines (lower case) and columns (upper case) ( $p<0.05)$; CV: coefficient of variation. 


\section{DISCUSSION}

The results observed for the densities of one and two parasitoid females (Table 1) are in accordance with the Local Mate Competition Theory (LMC), proposed by HAMILTON (1967). According to this theory, when only one female oviposits in a site, it tends to lay eggs that will produce females, and when the females are accompanied, it tends to oviposit a greater number of eggs that will produce males, so that it will mate with the available females. However, the results obtained for the higher female densities and lower larval densities offered in the present study were contrary to the LMC theory, i.e., in the presence of a very high number of females, the progeny sex ratio tended to increase.

The highest sex ratio and highest parasitism rate were obtained in the lowest ratio of host larvae/females (1:1) (Tables 1 and 2). Conversely, higher mortalities were obtained at lower host densities and higher female densities (Table 3), which might be related to superparasitism. Superparasitism is a specialty of parasitoid females in which an egg is deposited in a host that is already parasitized by another co-specific or by themselves (i.e., self superparasitism) (VAN ALPHEN; VISSER, 1990). Superparasitism might explain the greater emergence of females and the high parasitism rates obtained in ratios of 1:1 (larvae/ females) in the present study, since superparasitism is correlated to the highest ratio of females in the progeny of $D$. longicaudata (ALVARENGA et al., 2016; GONZÁLEZ et al., 2010; MONTOYA et al., 2011, 2012). In the past, superparasitism was considered to be a female error, attributed to the failure to discriminate an already parasitized host. However, nowadays it is understood as an adaptive advantage, in which the female increases the chances of her offspring surviving by laying more fertilized eggs inside the host (GONZÁLEZ et al., 2010). In this sense, when a female oviposits a previously parasitized host, then this would attain a higher reproductive expectation than if she decided to reject it (MANGEL, 1992).

Females, when dividing the same site with a co-specific, tend to increase their parasitism activity, which can lead to superparasitism (ALVARENGA et al., 2016), and that can be potentiated when small numbers of host larvae are offered (MONTOYA et al., 2000). Thus, females manifest the competitive behavior via superparasitism, probably with the objective of preventing their competitor from re-parasitizing the host that had already been superparasitized by it (GODFRAY, 1994).

Similar results were obtained by VAN NIEUWENHOVE et al. (2012), who evaluated the proportion of the host larvae of Anastrepha fraterculus (Wiedemann) (Diptera: Tephritidae) and females of $D$. longicaudata and established that ratios closer to 1:1 (host larvae/females), providing a higher parasitism rate and sex ratio. The authors observed a correlation between the superparasitized larvae and greater emergence of females. Superparasitism is an interesting factor to consider in mass rearing, but an excess of superparasitism can cause deleterious effects, resulting in pupal mortality, mainly in small densities of hosts. Thus, the high pupal mortalities observed in the present study for the ratios of few hosts and high densities of females (Table 3) could also be attributed to superparasitism, but in this case in excess.

As demonstrated, when confronted with a competitor, a female increases her parasitism activity, leading to superparasitism, especially in small host densities (ALVARENGA et al., 2016; MONTOYA et al., 2000). This phenomenon might have occurred in the present study, with up to $60.83 \%$ mortality seen when 10 host larvae were offered to 15 parasitoid females. Our hypothesis is supported by the study by GONZÁLEZ et al. (2007), who observed that moderate levels of parasitism (up to six oviposition scars/host larvae) were beneficial for the emergence of the parasitoid and increased the proportion of females in mass rearing. However, higher parasitism levels can significantly reduce the emergence of parasitoids. In this context, it can be verified that the ratios in which high levels of mortality were observed were the same as for higher rates of parasitism. Conversely, for the 1:1 ratio, in which $100 \%$ parasitism was observed, there was low pupal mortality. Females in these conditions had probably not superparasitized to levels

Table 3. Pupal mortality (\%) of Ceratitis capitata parasitized by Diachasmimorpha longicaudata.

\begin{tabular}{|c|c|c|c|c|c|c|}
\hline \multirow{2}{*}{$\begin{array}{l}\text { Number } \\
\text { of females }\end{array}$} & \multicolumn{5}{|c|}{ Number of larvae } & \multirow{2}{*}{ Mean } \\
\hline & 10 & 20 & 30 & 40 & 50 & \\
\hline 1 & $9.16 \mathrm{Ca}$ & $20.83 \mathrm{Ba}$ & 16.67 Ba & $12.50 \mathrm{Aa}$ & $8.33 \mathrm{Aa}$ & $13.50 \mathrm{~B}$ \\
\hline 2 & $26.67 \mathrm{Ba}$ & 20.42Bab & 15.55 Bab & 13.12 Aab & $8.66 \mathrm{Ab}$ & $16.89 \mathrm{~B}$ \\
\hline 5 & $20.83 \mathrm{BCa}$ & $7.92 \mathrm{Ba}$ & $6.94 \mathrm{Ba}$ & $10.00 \mathrm{Aa}$ & 12.83 Aa & $11.70 \mathrm{~B}$ \\
\hline 10 & 16.67 BCa & $13.75 \mathrm{Ba}$ & $12.50 \mathrm{Ba}$ & $17.50 \mathrm{Aa}$ & $12.33 \mathrm{Aa}$ & $14.55 \mathrm{~B}$ \\
\hline 15 & $60.83 \mathrm{Aa}$ & $45.42 \mathrm{Ab}$ & $36.39 \mathrm{Ab}$ & $19.58 \mathrm{AC}$ & 16.17 AC & $35.68 \mathrm{~A}$ \\
\hline Mean & $26.83 a$ & $21.67 \mathrm{ab}$ & $17.61 \mathrm{bc}$ & $14.54 \mathrm{c}$ & $11.67 \mathrm{c}$ & \\
\hline CV & \multicolumn{6}{|c|}{69.31} \\
\hline
\end{tabular}

'Different letters mean significance between the means, in the lines (lower case) and columns (upper case) $(p<0.05)$; CV: coefficient of variation. 
that had affected the larvae and, consequently, the emergence of the parasitoids.

Although several authors have constated the correlation between superparasitism and higher sex ratios, this hypothesis cannot broadly sustain the results obtained in the present study. As the intensity of superparasitism is evaluated by the number of oviposition scars left by the females at the time of oviposition and, in the present study the numbers of scars on the parasitized larvae were not recorded, it is not possible to affirm this correlation between superparasitism and higher sex ratios.

Females of D. longicaudata tend to manifest the behavior of competition by increasing their parasitism activity, as observed in the present study, and this competition may, under certain conditions, be favorable for mass rearing by increasing the rate of production and the number of females in the progeny. However, if the competitive environment is extreme, i.e., it stimulates a higher amount of superparasitism, to the point which it influences the emergence of parasitoids, competition among females becomes detrimental in mass rearing. It can be verified that, when we used a ratio of
1:1, a higher number of females in the progeny, high parasitism, and low mortality were observed. Conversely, when we reduced the number of host larvae, the females tended to increase oviposition activity due to the low supply of host larvae by females, which resulted in higher mortality rates, probably due to high superparasitism.

Therefore, from the results obtained, we recommend the supply of host larvae in a ratio equal to the number of females of D. longicaudata.

\section{ACKNOWLEDGMENTS}

The present study was supported by the Fundação de Amparo à Pesquisa do Estado de Minas Gerais (FAPEMIG) (grant number APQ-01422-12), Coordenação de Aperfeiçoamento de Pessoal de Nível Superior (CAPES) (granting the PhD scholarship), and Conselho Nacional de Desenvolvimento Científico e Tecnológico (CNPq) (grant number PQ-309676/2015-0).

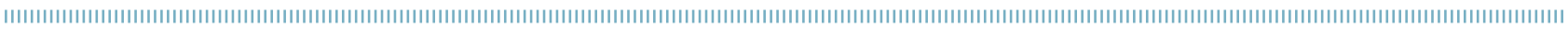
REFERENCES

ALVARENGA, C.D.; DIAS, V.; STUHL, C.; SIVINSKI, J. Contrasting brood-sex ratio flexibility in two Opiine (Hymenoptera: Braconidae) parasitoids of tephritid (Diptera) fruit flies. Journal of Insect Behavior, New York, v.29, n. 1, p.25-36, 2016.

CARVALHO, R.S. Estudos de laboratório e de campo com o parasitoide exótico Diachasmimorpha longicaudata Ashmead (Hymenoptera: Braconidae) no Brasil. 2003. 182 f. Tese (Doutorado em Entomologia) - Instituto de Biociências, Universidade de São Paulo, São Paulo, 2003.

CARVALHO, R.S.; NASCIMENTO, A.S.; MATRANGOLO, W.J.R. Metodologia de criação do parasitóide exótico Diachasmimorpha longicaudata (Hymenoptera: Braconidae), visando estudos em laboratório e em campo. Cruz das Almas: EMBRAPA/CNPMF. 1998. $16 p$.

DÍAZ-FLEISCHER, F.; GALVEZ, C.; MONTOYA, P. Oviposition, superparasitism, and eggload in the solitary parasitoid Diachasmimorpha longicaudata (Hymenoptera: Braconidae): response to host availability. Annals of the Entomological Society of America, Oxford, v.108, n.3, p.235-241, 2015.

FERREIRA, D.F. Sistema de Analise de Variância para dados balanceados. Lavras: Universidade Federal de Lavras. 2000.66p. (SISVAR 4.1. Pacote computacional).

GARCIA, F.R.M.; RICALDE, M.P. Augmentative biological control using parasitoids for fruit fly management in Brazil. Insects, Basel, v.4, n. 1, p.55-70, 2012.
GODFRAY, H.C.J. Parasitoids behavioral and evolutionary ecology. New Jersey: Princeton University Press, 1994. 474p.

GONZÁLEZ, P.I.; MONTOYA, P.; PEREZ-LACHAUD, G.; CANCINO, J.; LIEDO, P. Superparasitism in mass reared Diachasmimorpha longicaudata (Ashmead) (Hymenoptera: Braconidae), a parasitoid of fruit flies (Diptera: Tephritidae). Biological Control, Amsterdam, v.40, n.3, p.320-326, 2007.

GONZÁLEZ, P.; MONTOYA, P.; PEREZ-LACHAUD, G.; CANCINO, J.; LIEDO, $P$. Host discrimination and superparasitism in wild and mass-reared Diachasmimorpha longicaudata (Hym.:Braconidae) females. Biocontrol Science and Technology, Abingdon, v.20, n.2, p.137-148, 2010.

HAMILTON, W.D. Extraordinary sex ratios. Science, Princeton, v.156, n.3774, p.477-488, 1967.

MONTOYA, P.; LIEDO, P.; BENREY, B.; CANCINO, J.; BARRERA, J.F.; SIVINSKI, J.; ALUJA, M. Functional response and superparasitism by Diachasmimorpha longicaudata (Hymenoptera: Braconidae), a parasitoid of fruit flies (Diptera: Tephritidae). Annals of the Entomological Society of America, Lexington, v.93, n.3, p.47-54, 2000.

MANGEL, M. Descriptions of superparasitism by optimal foraging theory, evolutionar stable strategies and quantitative genetics. Evolutionary Ecology, Tucson, v.6, n.2, p.152-169, 1992.

MONTOYA, P.; CACINO, J.; PEREZ-LACHAUD, G.; LIEDO, P. Host size, superparasitism and sex ratio in mass-reared Diachasmimorpha longicaudata, a fruit fly parasitoid. Biological Control, Lexington, v.56, n. 1, p.11-17, 2011. 
MONTOYA, P.; PÉREZ-LACGHAUD, G.; LIEDO P. Superparasitism in the fruit fly parasitoid Diachasmimorpha longicaudata (Hymenoptera: Braconidae) and the implications for mass rearing and Augmentative release. Insects, Basel, v.3, n.4, p.900-911, 2012.

OLIVEIRA, P.C.C.; FONSECA, E.D.; ALVARENGA, C.D.; GIUSTOLIN, T.A.; RABELO, M.M.; COUTINHO, C.R. Efeito da idade das larvas de Ceratitis capitata (Wied.) sobre a qualidade biológica do parasitoide Diachasmimorpha longicaudata (Ashmead). Arquivos do Instituto Biológico, São Paulo, v.81, n.3, p.244-249, 2014.
VAN NIEUWENHOVE, G.A.; BEZDJIAN, L.P.; OVRUSKI, S.M. Effect of exposure time and ratio of hosts to female parasitoids on offspring production of Diachasmimorpha longicaudata (Hymneoptera: Braconidae) reared on Anastrepha fraterculus (Diptera: Tephritidae) larvae. Florida Entomologist, Gainesville, v.95, n.1, p.99-104, 2012

VAN ALPHEN, J.J.M.; VISSER, M.E. Superparasitism as an adaptive strategy for insect parasitoids. Annual Review of Entomology, Palo Alto, v.35, n.1, p.59-79, 1990. 